\title{
CHARACTERISTICS OF PREGNANT WOMEN WITH THE CHRONIC ENERGY DEFICIENCY AT THE PHC OF PASUNDAN GARUT
}

\author{
Rohiman $^{1}$, Imas Rafiyah ${ }^{2}$, Sukmawati $^{3}$ \\ ${ }^{1,2}$ Faculty of Nursing, Universitas Padjadjaran, ${ }^{3}$ PSDKU Garut, Universitas Padjadjaran \\ Correspondance: Ahmad.sukma@yahoo.co.id
}

\begin{abstract}
In 2016, community health center of Pasundan Garut was the first rank in terms of the total number of chronic deficiency energy for pregnant women in Garut. The characteristics of pregnant women with chronic energy deficiency (abbreviated as CED) are not definitely identified. This research is aimed to identify the characteristics of pregnant women with CED. This descriptive research used quantitative approach. The population of this study was 61 pregnant women with CED and the whole population was taken as samples. The research instrument was developed from the Child Identity Card book and the data was collected by using interview and documentation study. The result of the documentation study showed that most pregnant women with CED were at not risk age $(62.3 \%)$, not educated women $(59 \%)$, unemployed women $(68.9 \%)$, at not risk parity $(98.4 \%)$, birth spacing $\geq$ years $(54.1 \%)$, no pregnant complication found (78.7\%), no history of infectious diseases and allergies (85.2\%), consuming Fe tablets (68.9\%). The data collected through interview revealed that the respondents had low income $(85.2 \%)$ and no diverse diet $(59 \%)$ because they hardly to consume fruits, ate lack portion, had dietary restrictions and processed the food with the wrong manner. This research concludes that the main cause of CED in the community health center of Pasundan Garut is generally described based on the characteristics of family income and dietary pattern. Therefore, it is considered necessary to do counseling and guidelines to exploit and take full advantage of potential such as a vertical garden for self-sufficiency.
\end{abstract}

Keywords: Chronic Energy Deficiency, Characteristic, Pregnant Women.

\section{INTRODUCTION}

Pregnancy is a period in which a woman needs more nutrients than usual, this is due to physiological, anatomical and biochemical changes that have an impact on changes in nutritional needs and diet. All changes are useful for regulating metabolism, nutritional intake for the fetus, fetal growth, and preparing women for birth and breastfeeding (Putri \& Muqsith, 2015).

According to the Ministry of Health of the Republic of Indonesia in Indonesia in 2016, there were 5,355,710 pregnant women and West Java ranked first with the number of pregnant women numbering 975,636 or around 18.2\% (Budijanto, Hardhana, Yudianto, \& Soenardi, 2017). In Indonesia, one of the nutritional problems that are often experienced by women during pregnancy is a lack of chronic energy, especially the absence of a balance of nutritional intake so that nutrients that women need by the 
Rohiman: Characteristics Of Pregnant Women With The Chronic Energy Deficiency

body are not fulfilled (Adnyani \& Mertasari, 2016). In West Java in 2016, there were 80,000 pregnant women with a Chronic Energy Deficiency Risk (KEK) (Indonesian Ministry of Health, 2017).

Nutritional status during pregnancy not only affects the health of women but also affects the nutritional status of the fetus they contain, where the nutritional status of the fetus is determined by the food intake of pregnant women both during pregnancy and before pregnancy and significantly affects the health of women and fetuses (Lubis, 2003) in (Wachidah, Arifin, \& Hidayah, 2016).

KEK is a situation where a pregnant woman experiences food intake that is lacking and lasts long, marked by the emergence of health problems in pregnant women Sayogo (2007) in (Wachidah et al., 2016). Chronical energy deficiency in pregnant women has an impact on themselves or the fetus, where anemia during pregnancy, bleeding during labor, preterm labor and difficult and prolonged labor (Yuliastuti, 2014). Whereas according to Zuhaida (2005) in Wachidah et al., (2016) in pregnant women who experience malnutrition can cause anemia, bleeding during childbirth or postpartum, female weight gain is less than normal, preterm labor, fetal growth is inhibited, abortion, congenital defects, and low birth weight. Likewise the results of research conducted by $\mathrm{Pj}$, Kartasurya, \& Kartini (2015) in Bandung District, Tulungagung Regency, East Java showed that pregnant women with KEK had a risk three times greater for giving birth to Low Birth Weight Babies (less than 2500 grams).

Chronic Energy Deficiency in pregnant women may occur due to various factors. Such as age, family income, parity, birth distance, complications in pregnancy, medical history (Reeder, Martin, \& Koniak-Griffin, 2015), employment, diet (Arisman, 2009), education, and consumption of iron tablets (Yuliastuti, 2014). Age is used to determine the nutrients and calories that will be given. The economy is used if patients are below the poverty line or low-income family, aiming to see whether women are able to buy foods that contain nutrients during pregnancy. Obstetrics is useful for determining the amount of nutrition according to needs because too often pregnant can reduce the reserves of nutrients in the body (Arisman, 2009). For pregnant women, Health status is important because under unhealthy conditions the energy intake must be considered by consuming balanced nutrition. In eating habits, women are usually more concerned with 
food for the family than for themselves, women are required to have their pregnancies examined at least four times during pregnancy, one of the goals is to correct nutrition in pregnancy (Hutahaean, 2013).

In Garut Regency the number of pregnant women in 2016 reached 55,056 people and those who underwent Upper Arm Circulation (LILA) in 67 Puskesmas in Garut Regency as many as 46,145 pregnant women, from the results of the examination found 2,952 (6.3\%) pregnant women experienced LILA <23, 5 and Pasundan Health Center ranks first in pregnant women with KEK, of which 909 pregnant women who performed LILA examinations obtained 201 (22.1\%) pregnant women with LILA <23.5 (Garut District Health Office, 2017). In an interview conducted by researchers to Pasundan Puskesmas officers on March 5, 2018. The efforts made by the Pasundan Health Center to reduce KEK rates for pregnant women were by establishing classes of pregnant women since 2012 and providing supplementary food for pregnant women with KEK since 2015 however, the rate of KEK in pregnant women is still high.

To avoid the impact that will be caused by KEKs, it is important for nurses to make prevention as optimal as possible. In addition, pregnant women who have experienced KEKs must be given treatments to avoid the impact that will be caused both for the fetus or for the woman herself. Treatment can be done optimally if it is known how the characteristics of pregnant women with KEK. So far there is no data that shows how the characteristics of pregnant women with chronic energy deficiency in the work area of Pasundan health center. Based on the background above the researchers were interested in knowing the characteristics of pregnant women with chronic energy deficiency at the Pasundan Garut Health Center. The aim of this study was to identify the characteristics of pregnant women (age, education, occupation, family income, parity, birth distance, pregnancy complications, history of infectious and allergic diseases, consumption of tablets and diet) with chronic energy deficiencies in the Pasundan Garut health center

\section{METHODS}

This study was descriptive research. The variables in this study were the characteristics of pregnant women with KEK including age, family income, parity, birth spacing, 
pregnancy complications, history of infectious and allergic diseases, occupation, diet, education, and consumption of iron tablets. The samples in this study were 61 pregnant women with KEK who visited into Pasundan Garut Health Center, and they were chosen using the total sampling technique. Data collection was carried out using documentation studies and interviews. The study took place at the PHC Pasundan Garut Puskesmas from 27-29 July 2018. Data collection techniques began by coordinating with the PHC. the analysis in this study was carried out univariately. Analyzing the research variables by calculated proportions and frequencies to determine the characteristics of variables.

\section{RESULTS}

The following tables are presenting the study findings including characteristics of respondents and women's dietary patterns.

Table1. Characteristics of pregnant women with chronic energy deficiency $(\mathbf{n}=60)$

\begin{tabular}{|c|c|c|}
\hline Characteristic & $\mathbf{F}$ & $\%$ \\
\hline \multirow{4}{*}{$\begin{array}{l}\text { Age } \\
\text { High risk }(<20->35) \text { years } \\
\text { No Risk }(20-35) \text { years }\end{array}$} & & \\
\hline & 23 & 37.7 \\
\hline & & \\
\hline & 38 & 62.3 \\
\hline \multicolumn{3}{|l|}{ Formal education } \\
\hline Elementary & 11 & 18.0 \\
\hline Junior High School & 25 & 41.0 \\
\hline Senior High School & 25 & 41.0 \\
\hline University & 0 & 0 \\
\hline \multicolumn{3}{|l|}{ Employment Status } \\
\hline Worker & 19 & 31.1 \\
\hline Jobless & 42 & 68.9 \\
\hline \multicolumn{3}{|l|}{ Family's income } \\
\hline $\begin{array}{l}\geq 2 \mathrm{X} \text { Standard income ( Rp. } \\
3.350 .000 \text { ) }\end{array}$ & 9 & 14.8 \\
\hline $\begin{array}{l}<2 X \text { Standard income ( Rp. } \\
3.350 .000 \text { ) }\end{array}$ & 52 & 85.2 \\
\hline \multicolumn{3}{|l|}{ Parity } \\
\hline & 60 & 98.4 \\
\hline \multicolumn{3}{|l|}{ More than 4} \\
\hline & 1 & 1.6 \\
\hline \multicolumn{3}{|l|}{ Birth spacing } \\
\hline$<2$ years & 1 & 1.6 \\
\hline$\geq 2$ years & 33 & 54.1 \\
\hline No children & 27 & 44.3 \\
\hline \multicolumn{3}{|l|}{ Complication in pregnancy } \\
\hline None & 48 & 78.7 \\
\hline
\end{tabular}




\begin{tabular}{lcc}
\hline Anemia & 12 & 19.7 \\
Preeclampsia & 1 & 1.6 \\
\hline History of infectious disease & & \\
and allergy & 52 & 85.2 \\
None & 0 & 0 \\
Diarrhea & 1 & 1.6 \\
Tuberculosis & 0 & 0 \\
Gastritis & 0 & 0 \\
Typhoid & 0 & 0 \\
Diabetic & 8 & 13.1 \\
Others & & 68.9 \\
Iron tablet consumption & 42 & 31.1 \\
Yes & 19 & \\
No & & \\
\hline
\end{tabular}

Table 1 shows that pregnant women ages 20-35 years more experiencing chronic energy deficiency $(62.3 \%)$ compared to women at the risk age group $<20$ and $>35$ years as much (37.7\%). Pregnant women with chronic energy deficiency attended junior and senior high school education experienced chronic energy deficiency ( $41 \%$ and $41 \%$ ) compared to those with elementary education (18\%). Based on employment, pregnant women who did not have a job experienced chronic energy deficiency (68.9\%), while pregnant women who have a job had chronic energy deficiency $(31.1 \%)$.

Based on family income, women with wages $<2 \mathrm{X}$ standard income had chronic energy deficiency $(85.2 \%)$ more than women that get wages $\geq 2 \mathrm{X}$ standard income (14.8\%). Based on parity, women with the number of children 0-4 were the risk of $(98.4 \%)$ chronic energy deficiency and only (1.6\%) chronic energy deficiency occurs in women at risk. From birth spacing, women with a birth interval of $<2$ years only $(1.6 \%)$ and most women with a birth spacing > 2 years $(54.1 \%)$ and primigravid women were $(44.3 \%)$. (78.7\%) pregnant women without complications, $19.7 \%$ of women experienced anemia and (1.6\%) women experienced Preeclampsia. History of infectious and allergic diseases, found (85.2\%) women had no history of infectious and allergic diseases, (1.6\%) women experiencing Tuberculosis and (13.1) experiencing other diseases (amoxicillin allergies, bronchitis, animal food allergies, cold allergies, vertigo, history of post hernia, history of cysts and 
appendicitis). Based on, the majority of women consumed Fe tablets (68.9\%) and was not consumed Fe tablets $(31.1 \%)$.

Table 2. Diet for Pregnant Women with Chronic Energy Deficiency

\begin{tabular}{lcc}
\hline \multicolumn{1}{c}{ Characteristic } & F & $\%$ \\
\hline Yegetables & 44 & 72.1 \\
Nes & 2 & 3.3 \\
No & 15 & 24.6 \\
Sometimes & 20 & 32.8 \\
Fruits & 21 & 34.4 \\
Yes & 20 & 32.8 \\
No & & \\
Sometimes & 61 & 100.0 \\
Protein sources & 0 & 0 \\
Yes & & \\
No & 30 & 49.2 \\
Food portion & 31 & 50.8 \\
1 x more than before pregnant & & \\
Less than before pregnant & 12 & 80.7 \\
\hline Food restrictions & 49 & \\
Iya & & 42.5 \\
Tidak & & 57.4 \\
Cooking process & 26 & \\
Steam, Boil & 35 & 0 \\
Fried, Grill & & 23.0 \\
\hline Food sources & & \\
Buying & 47 & \\
Planting & 0 & \\
Preparing by family & 14 & \\
& &
\end{tabular}

\section{DISCUSSION}

Pregnant women need more nutrients than usual, due to physiological, anatomical and biochemical changes that affect changes in nutritional needs and diet. These changes are needed for metabolism, fetal nutrition, fetal growth, preparing for maternity, and breastfeeding (Putri \& Muqsith, 2015). Adnyani \& Mertasari (2016) states that in Indonesia chronic energy deficiency are a nutritional problem that is often experienced by women during pregnancy. According to Reeder et al. (2015), Arisman (2009) \& Yuliastuti (2014) Chronic Energy Deficiency occurs due to various factors such as age, education, work, family income, parity, birth distance, pregnancy complications, history of infectious and allergic diseases, Iron tablet consumption, and diet. 
Based on respondent characteristics, including age, education, occupation, parity, distance of birth, pregnancy complications, history of infectious and allergic diseases and consumption of Fe tablets, women are not at risk of Chronic Energy Deficiency, but from family income factors and women's diet, many women at risk of Chronic Energy Deficiency

In this study (85.2\%) family income $<2 \mathrm{X}$ of income standard and only $(14.8 \%) \geq$ $2 \mathrm{X}$ of income standard. The family's ability to buy food depends on family income. The food pattern is determined by the level of family income, the more money the better the ability to buy food to meet nutritional needs (Hamzah, 2017). According to Triatmaja (2017), low income affects the quantity of food consumed, and the big member of family size need more money for buying food, if the income is low it causes problems in food consumption. Anggraini (2013) and Lubis \& Aritonang (2015) study states that there is a significant relationship between the income of families with chronic energy deficiency in pregnant women. There are no women who plant crops to get their food, even though according to Desilliyarni, Sastuti, Fauzy, \& Endah (2003) say that farming in the home grounds, especially for urban people, aims to fulfill the needs of both vegetables and fruits consumed by the family. In addition to earning additional income for the family.

Lack of variety in diet, lack of food portions and food restrictions are factors that cause Chronic Energy Deficiency. Imbalance nutritional intake for women during pregnancy can cause interference for women or their fetuses. If it continues for a long time, this situation will cause an imbalance in the nutrient intake to meet energy needs, so that it can cause Chronic Energy Deficiency in women (Yuliastuti, 2014). In this study, it was found that $(59.0 \%)$ women ate no variety with balanced nutrition, while only $(41.0 \%)$ ate with balanced nutrition, more portion food than before pregnancy.

From the results of the study it was found that most women consumed vegetables $(72.1 \%)$, and all women ate side dishes (100.0\%), but when viewed from how to process food more women processed food by frying or burning as much (57.4\%). According to Sugani \& Priandarini (2010), the best way to cook is by stirfrying, steaming and boiling. This method is good because the nutrients in the food are well maintained. In contrast, the majority of women were processing food by being 
fried, smoked or grill, these methods can damage the nutrients in food. When food is burned it will form a heterocyclic amine compound (Has) and Polycyclic Aromatic Hydro Carbon (PAHs) both of these compounds cause cancer of the breast, intestine, stomach, and prostate. Then the protein in the heat which is heated too long will change and form a residue that stimulates the growth of cancer cells in the body.

Most women do not consume fruit during pregnancy (34.4\%) and as many $(32.8 \%)$ women rarely consume fruit. fruit is important for increasing endurance. From the portion of food, more women eat the same or less than before pregnancy $(50.8 \%)$. With regard to culture, there are 12 women (19.7\%) having dietary restrictions, such as goat or beef chicken liver, skin, and fruits like pineapple.

\section{CONCLUSIONS}

It was concluded that pregnant women in the Garut Pasundan Health Center in January to May 2018 were generally not at risk of Chronic Energy Deficiency, but when viewed from family income and diet, women were more at risk of experiencing chronic energy deficiency. There needs to be an effort to examine what actually causes the Chronic Energy Deficiency of Pasundan Garut Health Center. Re-analyzing the data are needed to formulate the cause of the problem, make a diagnosis, solve the problem with short-term and long-term goals, intervene and evaluate the results. One program is that health workers advice to women is developing vertical gardens by utilizing and maximizing the yard.

\section{REFERENCES}

Adnyani, N. W. S., \& Mertasari, L. P. R. (2016). Hubungan Status Gizi Perempuan Hamil Dengan Peningkatan Berat Badan Janin Di Klinik Wiratni Tahun 2016 Oleh:, 6(2), 113-115.

Anggraini, Y. (2013). Pengaruh Demogafi dan Sosio Ekonomi pada Kejadian Kekurangan Energi Kronik Perempuan hamil di Kota Metro Provinsi Lampung. Jurnal Kesehatan, 4(2), 401-407.

Arisman. (2009). Buku Ajar Ilmu gizi. Gizi dalam Daur Kehidupan. (Suryani, Ed.) (edisi 2). Jakarta: penerbit buku kedokteran EGC. 
Budijanto, D., Hardhana, B., Yudianto, \& Soenardi, T. (2017). Data and Information Indonesia Health Profile 2016. Profil Kesehatan indonesia2016, 168. Retrieved from http://www.depkes.go.id/resources/download/pusdatin/lain-lain/Data dan Informasi Kesehatan Profil Kesehatan Indonesia 2016 - smaller size - web.pdf

Desilliyarni, T., S]astuti, Y., Fauzy, F., \& Endah, J. (2003). Vertikultur Teknik Bertanam di Lahan Sempit. Tangerang: Agro Media Pustaka.

Hamzah, D. F. (2017). Analisis Faktor Yang Memengaruhi Kejadian Kekurangan Energi Kronis (Kek) Pada Perempuan Hamil Di Wilayah Kerja Puskesmas Langsa Kota Kota Langsa Provinsi Aceh Tahun 2016. Jurnal JUMANTIK, 2(2), 1-11.

Hutahaean, S. (2013). Perawatan Antenatal. (A. Suslia, Ed.). Jakarta: selemba Medika.

Lubis, lili angriani, Lubis, Z., \& Aritonang, E. (2015). Faktor-Faktor Yang Berhubungan Dengan Kejadian Kekurangan Energi Kronik (Kek) Pada Perempuan Hamil Di Puskesmas Langsa Lama Kota Langsa Tahun 2015, 30(20), 223-228.

Pj, S. K., Kartasurya, M. I., \& Kartini, A. (2015). Status Gizi Pada Perempuan Hamil Sebagai Faktor Risiko Kejadian Berat Bayi Lahir Rendah. Jurnal Kesehatan Masyarakat, 3, 286-294.

Putri, A. R., \& Muqsith, A. (2015). Hubungan Lingkar Lengan Atas Perempuan Hamil Dengan Berat Badan Lahir Bayi Di Rumah Sakit Umum Cut Meutia Kabupaten Aceh Utara Dan Rumah Sakit Tk Iv Im.07.01 Lhokseumawe Tahun 2015. Jurnal Kedokteran Dan Kesehatan Malikussaleh, 1-7.

Reeder, S. J., Martin, L. L., \& Koniak-Griffin, D. (2015). Keperawatan Maternitas kesehatan wanita, bayi \& keluarga. (E. A. Mardella, D. Yulianti, N. B. Subekti, \& P. E. Karyuni, Eds.) (Edisi 18). Jakarta: penerbit buku kedokteran EGC.

Sugani, dr. S., \& Priandarini, L. (2010). CARA CERDAS untuk SEHAT. Jakarta: transmedia Pustaka.

Triatmaja, N. T. (2017). Faktor-Faktor Yang Berhubungan Dengan Status Kurang Energi Kronis ( Kek ) Perempuan Hamil Di Kabupaten Kediri, 4(2), 137-142.

Wachidah, U., Arifin, S., \& Hidayah, N. (2016). Karakteristik Umur Dan Paritas Perempuan Hamil Dengan Kurang Energi Kronik (Kek) Di Puskesmas Kelayan Timur Tahun 2015.

Yuliastuti, E. (2014). Faktor-Faktor yang Berhubungan dengan Kekurangan Energi Kronis pada Perempuan hamil di Wilayah Kerja Puskesmas Sungai Bilu Banjarmasin. An Nadaa, 1(2), 72-76. 